co-operative in all phases of the study. The missing information at the initial stage occurred randomly and it is not likely to cause bias. Hence the problems related to the initial examination do not invalidate our findings.

In a cross sectional analysis the plasma glucose concentration one hour after a glucose load was, independently of body weight, associated with blood pressure, even in schoolchildren aged 9-12. ${ }^{3}$ In our follow up study the glucose concentration after one hour was a strong predictor of future hypertension in adults. Thus a latent abnormality of glucose metabolism and blood pressure may last for decades without clinical manifestation. It is often combined with dyslipidemia ${ }^{190}$ and may play an important part in the development of atherosclerosis and coronary heart disease.

We thank Ms Jaana Räbinä for secretarial help and the Finnish Foundation for Cardiovascular Research, Kymenlaakson Terveyden Turva, and Suomen Kulttuurirahaston Kymenlaakson rahasto for financial support.

1 Stamler J, Rhomberg P, Schoenberger JA, et al. Multivariate analysis of the relationship of seven variables to blood pressure: findings of the Chicago Heart Association detection project in industry, 1967-1972. F Chronic Dis $1975 ; 28: 527-48$

2 Jarret RJ, Keen H, McCartney M, et al. Glucose tolerance and blood pressure in two population samples: their relation to diabetes mellitus and hypertension. Int $\mathcal{F}$ Epidemiol 1987;7:15-24.

3 Florey C du V, Uppal S, Lowy C. Relation between blood pressure, weight, and plasma sugar and serum insulin levels in schoolchildren aged 9-12 years in Westland, Holland. BMF 1976; i:1368-71.

4 Reaven PD, Barret-Connor EL, Browner DK. Abnormal glucose tolerance and hypertension. Diabetes Care 1990;13:119-25.
5 Miettinen TA, Huttunen JK, Naukkarinen V, et al. Multifactorial primary prevention of cardiovascular diseases in middle-aged men. Risk factors changes, incidence and mortality. FAMA 1985;254:2097-102.

6 Naukkarinen VA, Strandberg TE, Vanhanen HT, Salomaa VV, Sarna SJ, Miettinen TA. Mortality rates after multifactorial primary prevention of cardiovascular diseases. Annals of Medicine 1989;21:441-6.

7 Kessler G, Lederer H. Fluorometric measurement of triglycerides. In: Skeges LT, ed Automation in analytical chemistry. New York: Mediad, 1966:341

Hultan E Rapid specific method for determination of aldosacharides in body fluids. Nanure 1959;183:108-9.

9 Dixon WJ, ed. BMDP statistical software. Berkeley: University of California Press, 1985.

10 Ferrannini E, Buzzigoli G, Bonnadonna R, et al. Insulin resistance in essential hypertension. $N$ Engl f Med 1987;317:350-7.

11 Modan M, Halkin H, Almog S, et al. Hyperinsulinemia. A link between hypertension, obesity and glucose intolerance. $\mathcal{F}$ Clin Invest 1985;75:809-17.

12 Fournier AM, Gadia MT, Kubrusly DB, Skyler JS, Sosenko JM. Blood pressure, insulin and glycemia in nondiabetic subjects. Am f Med 1986;80: $861-4$

13 Porta M, Molinatti GM. Insulin resistance in hypertension. $N$ Engl $\mathcal{F}$ Med 1988;318:383

14 Mbanya J-CN, Thomas TH, Wilkinson R, Alberti KGMM, Taylor R. Hypertension and hyperinsulinemia: a relation in diabetes but not in essential hypertension. Lancet 1988;i:733-4.

15 World Health Organisation Study Group. Diabetes mellitus. WHO Tech Rep Ser 1985; No 727 .

16 Gardner MJ, Heady JA. Some effects of within-person variability in epidemiological studies. 7 Chronic Dis 1973;26:781-95.

17 MacMahon S, Peto R, Cutler J, et al. Blood pressure, stroke and coronary heart disease. Part 1, prolonged differences in blood pressure: prospective observational studies corrected for the regression dilution bias. Lancet 1990;335:765-74.

18 Mattila S. Correlation between ECG abnormalities observed in health examinations and coronary heart disease in middle-aged men [Dissertation]. Helsinki, Finland: University of Helsinki, 1980. (Finnish with English summary.)

19 Zavaroni I, Bonora E, Pagliara M, et al. Risk factors for coronary artery disease in healthy persons with hyperinsulinemia and normal glucose tolerance. $N$ Engl f Med 1989;320:720-6.

20 Foster DW. Insulin resistance-a secret killer? N Engl f Med 1989;320:733-4.
Projet Retro-CI, Abidjan, Ivory Coast

Kevin M De Cock, MD,

director

Emmanuel Gnaore, MD, medical officer

Georgette Adjorlolo, MD, medical officer

Marie-France Lafontaine, computer specialist

Gilberte Yesso, MD, medical officer

International Activity, Division of HIV and AIDS, Center for Infectious

Diseases, Centers for Disease Control, Atlanta, Georgia, United States

M Miles Braun, MD, medical officer

William L Heyward, MD, chief

Centres Antituberculeux, Abidjan, Ivory Coast Issa M Coulibaly, MD, medical officer

Raymond Bretton, $\mathrm{MD}$, chief medical officer

Genevieve Bretton, MD, medical officer

Institute Pasteur de Cote d'Ivoire, Ivory Coast Guy-Michel Gershy-Damet, PHD, microbiologist

Correspondence to: Dr De Cock.

\title{
Risk of tuberculosis in patients with HIV-I and HIV-II infections in Abidjan, Ivory Coast
}

Kevin M De Cock, Emmanuel Gnaore, Georgette Adjorlolo, M Miles Braun, Marie-France Lafontaine, Gilberte Yesso, Genevieve Bretton, Issa M Coulibaly, Guy-Michel Gershy-Damet, Raymond Bretton, William L Heyward

\section{Abstract}

Objective-To examine the association between HIV-II infection and tuberculosis.

Design-Cross sectional study comparing the prevalence of HIV-I and HIV-II infections in patients with tuberculosis and in blood donors.

Setting-Abidjan, Ivory Coast, west Africa.

Patients-2043 consecutive ambulant patients with tuberculosis (confirmed pulmonary, presumed pulmonary, or extrapulmonary) and 2127 volunteer blood donors.

Main outcome measure-Prevalence of HIV-I and HIV-II infections as assessed by presence of serum antibodies.

Results-Overall rates of HIV infection were $40.2 \%$ in patients with tuberculosis $(26.4 \%$ positive for HIV-I, $\mathbf{4 . 7 \%}$ for HIV-II, and $\mathbf{9 . 0 \%}$ for both); and $10.4 \%$ in blood donors $(7.2 \%$ positive for HIV-I, $1.9 \%$ for HIV-II, and $1.3 \%$ for both). HIV-II infection was significantly more common in patients with all types of tuberculosis than in blood donors (97/2043, $4.7 \% v 40 / 2127,1.9 \%$; odds ratio $3.8 \%$, $95 \%$ confidence interval $2 \cdot 6$ to $5 \cdot 6$ ).

Conclusion-Both HIV-I and HIV-II infection are associated with tuberculosis in Abidjan. $35 \%$ of adult tuberculosis in Abidjan is attributable to HIV infection and $4 \%$ specifically to HIV-II.

\section{Introduction}

Human tuberculosis is a recognised complication of infection with HIV-I. ${ }^{2}$ In the United States a relative increase in the incidence of tuberculosis has been found in areas with high rates of AIDS, affecting certain population groups with the highest incidences of AIDS most severely. ${ }^{3}$ Many seroepidemiological studies have shown high rates of HIV-I infection in patients with tuberculosis, and cohort studies in the United States ${ }^{4}$ and Zaire 5 have shown that patients infected with HIV-I are at increased risk of developing active tuberculosis.

Whether or not tuberculosis is an opportunistic disease complicating infection with HIV-II is uncertain. ${ }^{6}$ Although HIV-II infection is clearly associated with AIDS,${ }^{78}$ it has been suggested that the natural course of this infection differs considerably from that of infection with HIV-I (P Kanki et al, fifth international conference on AIDS, Montreal, 1989)..$^{90}$ Work from the Cape Verde Islands (D Andrade $e t a l$, third international conference on AIDS and associated cancers in Africa, Arusha, 1988) and Guinea-Bissau ${ }^{11}$ has suggested high levels of HIV-II infection in patients with tuberculosis, yet reports from Angola (M J M Almeida et al, fifth international conference on AIDS, Montreal, 1989), Benin (I Zouhoun et al, fourth international conference on AIDS, Stockholm, 1988), Mali (F Brun-Vezinet et al, fourth international conference on AIDS, Stockholm, 1988), and the Ivory Coast (M Braun et al, fifth international conference on AIDS, Montreal, 1989) did not show a definite association.

We compared levels of HIV-I and HIV-II infections in patients with tuberculosis and blood donors in Abidjan, Ivory Coast, where both viruses are present, 
to clarify the association between tuberculosis and infection with HIV-II.

\section{Patients and methods}

From July 1989 to January 1990 consecutive ambulant patients diagnosed as having tuberculosis at Abidjan's two tuberculosis treatment centres were tested for HIV infection and counselled. A history was taken from all patients. They also had a physical examination, including radiography of the chest and a tuberculin skin test; expectorated sputum was examined for acid fast bacilli using the Ziehl-Neelsen method. Standard treatment for tuberculosis prescribed for all patients was rifampicin and isoniazid for six months with pyrazinamide for the first two months.

Patients were considered to have confirmed pulmonary tuberculosis when acid fast bacilli were found on direct microscopic examination of smears of expectorated sputum. Presumed pulmonary tuberculosis was diagnosed in patients with consistent clinical and radiological features but whose sputum smears gave negative results. Extrapulmonary tuberculosis was presumptively diagnosed in patients whose sputum smears gave negative results but who had suggestive clinical findings. We considered patients whose sputum smears contained acid fast bacilli who also had signs of extrapulmonary dissemination to have pulmonary tuberculosis.

Volunteer blood donors were used as controls on the assumption that they were a healthy population and did not have clinical tuberculosis. Basic demographic details, including age, sex, and nationality, were collected from consecutive blood donors recruited during the study period by the national blood transfusion service. Most blood donors were first time donors.

Serum specimens from patients with tuberculosis and blood donors were tested for antibodies to HIV-I and HIV-II using a previously described testing strategy that included whole virus enzyme linked immunosorbent assay (ELISA) (Genetic Systems, Seattle), virus specific western blotting ( $\mathrm{Du}$ Pont de Nemours, Geneva for HIV-I and Diagnostics Pasteur, Paris for

TABLE I-Demographic features of study populations

\begin{tabular}{|c|c|c|}
\hline & $\begin{array}{l}\text { Patients with } \\
\text { tuberculosis } \\
(\mathrm{n}=2043)\end{array}$ & $\begin{array}{l}\text { Blood donors } \\
\quad(\mathbf{n}=2127)\end{array}$ \\
\hline \multicolumn{3}{|c|}{ Sex of No $(\%)$ of patients: } \\
\hline Male & $1510 \quad(73 \cdot 9)$ & $1670(78 \cdot 5)$ \\
\hline Female & $531 \quad(26 \cdot 0)$ & $431(20 \cdot 3)$ \\
\hline Unknown & $2 \quad(0 \cdot 1)$ & $26(1 \cdot 2)$ \\
\hline \multicolumn{3}{|l|}{ Age (years): } \\
\hline Mean (SD) & $32 \cdot 6(13 \cdot 5)$ & $26(7 \cdot 3)$ \\
\hline Median & & 24 \\
\hline Range & $0-85$ & $15-60$ \\
\hline \multicolumn{3}{|c|}{ Country of birth of No (\%) of patients: } \\
\hline Ivory Coast & $1004 \quad(49 \cdot 1)$ & $1981(93 \cdot 1)$ \\
\hline Other & $1023(50 \cdot 1)$ & $127(6 \cdot 0)$ \\
\hline Unknown & $16 \quad(0 \cdot 8)$ & $19(0.9)$ \\
\hline
\end{tabular}

TABLE II-Comparison of prevalence of HIV-I and HIV-II infections in patients with tuberculosis and in blood donors

\begin{tabular}{|c|c|c|c|c|c|}
\hline \multirow[b]{2}{*}{ Diagnostic group } & \multirow[b]{2}{*}{$\begin{array}{c}\text { No of } \\
\text { patients }\end{array}$} & \multicolumn{4}{|c|}{ No $(\%)$ of patients } \\
\hline & & $\begin{array}{l}\text { Positive for } \\
\text { HIV-I }\end{array}$ & $\begin{array}{l}\text { Positive for } \\
\text { HIV-II }\end{array}$ & $\begin{array}{l}\text { Positive for } \\
\text { HIV-I and HIV-II }\end{array}$ & $\begin{array}{l}\text { Total No positive } \\
\text { for HIV }\end{array}$ \\
\hline $\begin{array}{l}\text { Confirmed pulmonary tuberculosis } \\
\text { Presumed pulmonary tuberculosis } \\
\text { Extrapulmonary tuberculosis }\end{array}$ & $\begin{array}{r}1610 \\
120 \\
313\end{array}$ & $\begin{array}{r}390(24 \cdot 2) \\
37(30 \cdot 8) \\
113(36 \cdot 1)\end{array}$ & $\begin{array}{r}83(5 \cdot 2) \\
5(4 \cdot 2) \\
9(2 \cdot 9)\end{array}$ & $\begin{aligned} & 136(8 \cdot 4) \\
& 11(9 \cdot 2) \\
& 37(11 \cdot 8)\end{aligned}$ & $\begin{array}{r}609(37 \cdot 8) \\
53(44 \cdot 2) \\
159(50 \cdot 8)\end{array}$ \\
\hline Total No with tuberculosis & 2043 & $540(26 \cdot 4)$ & $97(4 \cdot 7)$ & $184(9 \cdot 0)$ & $821(40 \cdot 2)$ \\
\hline Total No of blood donors & 2127 & $154(7 \cdot 2)$ & $40(1 \cdot 9)$ & $27(1 \cdot 3)$ & $221(10 \cdot 4)$ \\
\hline Odds ratio ( $95 \%$ confidence interval) & & $5 \cdot 5(4 \cdot 5$ to $6 \cdot 7)$ & $3.8(2.6$ to $5 \cdot 6)$ & $10 \cdot 6(6 \cdot 9$ to $16 \cdot 4)$ & $5.8(4.9$ to 6.9$)$ \\
\hline
\end{tabular}

HIV-II), and synthetic peptide based tests (Peptilav 1-2, Diagnostics Pasteur, Paris). ${ }^{8}$ Specimens were characterised as reactive to either HIV-I or HIV-II, or both ("dually reactive") or non-reactive. ${ }^{8}$

We analysed the results using computer software packages for statistical analyses (Epiinfo, version 5, Centers for Disease Control, Atlanta; statistical package for the social sciences (SPSS)). ${ }^{12}$ To compare the strength of association between tuberculosis and HIV-I and HIV-II infections we compared the prevalence of HIV-I and HIV-II infections in patients and controls. Odds ratios and their $95 \%$ confidence intervals were calculated. A Mantel-Haenszel weighted odds ratio was calculated for selected data that were stratified by age group. Certain comparisons were made using the $\chi^{2}$ test and Fisher's test of exact probability (two tailed). Means of continuous variables that were not normally distributed were compared using Wilcoxon's rank sum test. $\alpha$ Was set at 0.05 for all statistical tests.

The proportions of tuberculosis cases attributable to HIV-I and HIV-II infections in patients positive for HIV (the aetiological fraction among the exposed population) and in the population as a whole (the population aetiological fraction) were calculated using standard equations ${ }^{12}$; we assumed that the prevalence of HIV-I and HIV-II infections in volunteer blood donors was representative of that in the general population.

\section{Results}

We studied a total of 2043 consecutive patients with tuberculosis and 2127 consecutive blood donors. Of the patients with tuberculosis $1610 \mathrm{had}$ confirmed pulmonary tuberculosis, 120 presumed pulmonary tuberculosis, and 313 extrapulmonary tuberculosis. Culture of a limited number of sputum smears that gave positive results yielded organisms of the Mycobacterium tuberculosis complex with no evidence of atypical mycobacteria. ( $\mathrm{R}$ W Smithwick, personal communication).

Table I shows the demographic features of patients and blood donors. Blood donors were younger than patients with tuberculosis, more of them were men, and they were more often born in the Ivory Coast. Table II shows the relative numbers of patients positive for HIV-I and HIV-II in patients with tuberculosis stratified by type of disease and in blood donors. Overall, $821(40 \cdot 2 \%)$ patients with tuberculosis were positive for HIV-I or HIV-II, or both, compared with $221(10 \cdot 4 \%)$ blood donors (odds ratio 5.8, 95\% confidence interval $4 \cdot 9$ to 6.9). Each type of serological profile was significantly more common in patients with tuberculosis than in blood donors (table II) in each of the three categories of tuberculosis. The higher overall prevalence of HIV infection in patients with extrapulmonary tuberculosis $(50.8 \%)$ or presumed pulmonary tuberculosis $(44 \cdot 2 \%)$ than in patients with confirmed pulmonary tuberculosis $(37 \cdot 8 \%)$ was due to higher levels of HIV-I infection.

Blood donors and patients with tuberculosis with HIV-II infection were slightly older than patients with other serological profiles. The median ages of the male and female patients who were HIV-II positive were 37 years and 32 years respectively. For HIV-I infection the respective median ages in male and female patients with tuberculosis were 31 years and 25 years and for dually reactive patients 34 years and 25 years. Among blood donors a similar age distribution was seen for the different serological profiles, with HIV-II positive donors being older than those who were HIV-I positive or dually reactive. Overall, patients with tuberculosis were older than blood donors with a difference in mean or median ages between the two groups that was similar for the various serological profiles. 


\begin{tabular}{|c|c|c|c|c|c|c|}
\hline \multirow[b]{2}{*}{$\begin{array}{l}\text { Age } \\
\text { (years) }\end{array}$} & \multirow[b]{2}{*}{ Group } & \multirow[b]{2}{*}{$\begin{array}{c}\text { No of } \\
\text { patients }\end{array}$} & \multicolumn{4}{|c|}{ No $(\%)$ of patients } \\
\hline & & & $\begin{array}{l}\text { Positive for } \\
\text { HIV-I }\end{array}$ & $\begin{array}{l}\text { Positive for } \\
\text { HIV-II }\end{array}$ & $\begin{array}{l}\text { Positive for } \\
\text { HIV-I and HIV-II }\end{array}$ & $\begin{array}{l}\text { Total No positive } \\
\text { for HIV }\end{array}$ \\
\hline $20-29\{$ & $\begin{array}{l}\text { Patients with tuberculosis } \\
\text { Donors }\end{array}$ & $\begin{array}{r}263 \\
1229\end{array}$ & $\begin{array}{l}72(27 \cdot 4) \\
79(6 \cdot 4)\end{array}$ & $\begin{array}{r}9(3 \cdot 4) \\
17(1 \cdot 4)\end{array}$ & $\begin{array}{ll}16(6 \cdot 1) \\
13(1 \cdot 1)\end{array}$ & $\begin{array}{r}97(36.9) \\
109(8.9)\end{array}$ \\
\hline $30-39\{$ & $\begin{array}{l}\text { Patients with tuberculosis } \\
\text { Donors }\end{array}$ & $\begin{array}{l}197 \\
356\end{array}$ & $\begin{array}{l}52(26 \cdot 4) \\
33(9 \cdot 3)\end{array}$ & $\begin{array}{l}19(9 \cdot 6) \\
14(3 \cdot 9)\end{array}$ & $\begin{array}{r}24(12 \cdot 2) \\
8(2 \cdot 2)\end{array}$ & $\begin{array}{l}95(48 \cdot 2) \\
55(15 \cdot 4)\end{array}$ \\
\hline 40-49 & $\begin{array}{l}\text { Patients with tuberculosis } \\
\text { Donors }\end{array}$ & $\begin{array}{l}90 \\
79\end{array}$ & $\begin{array}{l}17(18.9) \\
11(13.9)\end{array}$ & $\begin{array}{l}8(8 \cdot 9) \\
2(2 \cdot 5)\end{array}$ & $\begin{array}{l}9(10 \cdot 0) \\
1(1 \cdot 3)\end{array}$ & $\begin{array}{l}34(37 \cdot 8) \\
14(17 \cdot 7)\end{array}$ \\
\hline 50-59 & $\begin{array}{l}\text { Patients with tuberculosis } \\
\text { Donors }\end{array}$ & $\begin{array}{l}63 \\
27\end{array}$ & $\begin{array}{ll}6 & (9 \cdot 5) \\
1 & (3 \cdot 7)\end{array}$ & $5(7 \cdot 9)$ & $1(1 \cdot 6)$ & $\begin{array}{r}12(19 \cdot 0) \\
1(3 \cdot 7)\end{array}$ \\
\hline Total \{ & $\begin{array}{l}\text { Patients with tuberculosis } \\
\text { Donors }\end{array}$ & $\begin{array}{r}613 \\
1691\end{array}$ & $\begin{array}{l}147(24 \cdot 0) \\
124(7 \cdot 3)\end{array}$ & $\begin{array}{l}41(6 \cdot 7) \\
33(2 \cdot 0)\end{array}$ & $\begin{array}{ll}50 & (8 \cdot 2) \\
22 & (1 \cdot 3)\end{array}$ & $\begin{array}{l}238(38 \cdot 8) \\
179(10 \cdot 6)\end{array}$ \\
\hline $\begin{array}{r}\text { Mantel } \\
\text { inter }\end{array}$ & $\begin{array}{l}\text { l-Haenszel weighted odds } \\
\text { rval) }\end{array}$ & nfidence & $4 \cdot 7(3 \cdot 6$ to $6 \cdot 2)$ & $4 \cdot 2(2 \cdot 5$ to $7 \cdot 4)$ & $8.9(5 \cdot 1$ to $15 \cdot 5)$ & \\
\hline
\end{tabular}

To allow for differences in the age specific prevalences of HIV-I and HIV-II infections, as well as for the unequal age distribution of the two study populations, we compared the frequency of the various serological profiles in patients with tuberculosis and blood donors stratified by age. The data in table III are restricted to people born in the Ivory Coast to avoid the possible confounding effect of nationality on prevalence of HIV infection. ${ }^{14}$ The analysis was restricted to patients with confirmed pulmonary tuberculosis to avoid including other HIV related disease potentially misdiagnosed as tuberculosis.

No cases of HIV-II infection were found in patients with confirmed pulmonary tuberculosis and blood donors aged less than 20 years, and dual reactivity in this age group was also extremely uncommon. For people aged 20-59 reactivity to HIV-I, HIV-II, and both viruses was significantly more common in patients with confirmed pulmonary tuberculosis than in blood donors (table III).

The distribution of tuberculin skin reactivity according to serological profile is shown in the figure. A

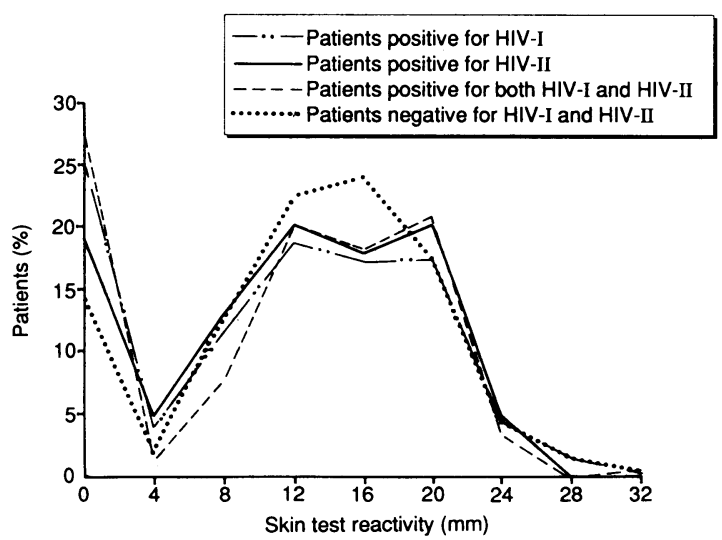

Tuberculin skin test reactivity in patients with tuberculosis with different serological profiles

negative tuberculin skin test (skin reaction $<8 \mathrm{~mm}$ ) was more common in patients positive for HIV than in patients negative for HIV, although most seropositive patients had positive skin tests. A significantly greater proportion of HIV-II positive patients with confirmed pulmonary tuberculosis had a negative skin test than seronegative patients (17/72 $v 118 / 810$; odds ratio $1 \cdot 8$ (95\% confidence interval $1 \cdot 0$ to $3 \cdot 3$ ). The increased frequency of negative skin tests in HIV-I positive and dually reactive patients was also significant.

For the calculation of aetiological fraction the odds ratio was derived from a comparison of the overall prevalence in adult ( $>14$ years) patients with tuberculosis $(803 / 1903,42 \cdot 2 \%)$ and blood donors $(221 / 2127,10 \cdot 4 \%)(6 \cdot 3,5 \cdot 3$ to $7 \cdot 5)$. The aetiological fraction in the exposed population was calculated to be $84 \%$. The population aetiological fraction was $35 \%$. For HIV-I infection specifically the population aetiological fraction was $23 \%$, for HIV-II infection $4 \%$, and for dual reactivity $8 \%$.

\section{Discussion}

Consecutive patients with newly diagnosed tuberculosis in Abidjan had a significantly higher rate of infection with HIV-I and HIV-II as well as a higher rate of reactivity to both viruses than consecutive blood donors in the same city. These associations remained when only patients with confirmed pulmonary tuberculosis were considered and when the data were stratified by age and country of birth. Although not perfectly representative of the general population, Abidjan blood donors have a prevalence of HIV infection similar to that in other sentinel groups such as women of reproductive age (E Gnaore et al, fourth international conference on AIDS and associated cancers in Africa, Marseille, 1989). ${ }^{15}$ These results suggest that neither misclassification nor the confounding factors of age or nationality nor selection bias towards donors negative for HIV could account for the association between tuberculosis and HIV-II infection.

We have shown previously ${ }^{8}$ that signs and symptoms common in HIV-I associated AIDS in Africa ${ }^{16}$ are found more often in patients positive for HIV-II than in hospital patients negative for HIV-II. The association with tuberculosis and the increased rate of tuberculin anergy compared with that in seronegative patients provide further evidence that infection with HIV-II is a pathogenic process with a similar spectrum of clinical manifestations as HIV-I infection. Patients and blood donors with HIV-II infection tended to be older than their counterparts in other serological groups, in keeping with other reports. ${ }^{81718}$ The differences in mean or median ages between patients with tuberculosis and blood donors, however, were similar across the different serological profiles (HIV-I, HIV-II, and dually reactive). Conclusions on the incubation periods of disease due to HIV-I or HIV-II infection should not be drawn from such cross sectional data.

From our calculations of the aetiological fraction $84 \%$ of cases of tuberculosis in HIV positive adults in Abidjan and $35 \%$ of all (HIV positive and HIV negative) new cases in adults were attributable to HIV infection. Of all new adult cases of tuberculosis, $4 \%$ were specifically attributable to HIV-II infection. In Africa tuberculosis may be the commonest opportunist infection complicating HIV infection and arguably the most important, being common, contagious, and treatable. In sub-Saharan Africa, including HIV-II endemic areas, rates of tuberculosis will increase because of the epidemic of HIV infection. Efforts to control tuberculosis in sub-Saharan Africa can no 
longer be dissociated from public health programmes for preventing and managing infection with HIV-I and HIV-II.

We thank Dr M Sassan-Morokro, Ms A Porter, and the laboratory staff of Projet Retro-CI; the staff of the Centres Antituberculeux in Abidjan; Mr R Smithwick for mycobacterial cultures; Dr D Ouattara for allowing us to study blood donors; and Professor K Odehouri and Dr H Gayle for discussion and advice. This study was supported in part by a grant from the global programme on AIDS, World Health Organisation.

1 Murray JF. The white plague: down and out, or up and coming? Am Rev Respir Dis 1989;140:1788-95.

2 Chaisson R, Slutkin G. Tuberculosis and human immunodeficiency virus infection. F Infect Dis 1989;159:96-100.

3 Rieder HL, Cauthen GM, Kelly GD, Bloch AB, Snider DE. Tuberculosis in the United States. FAMA 1989;262:385-9.

4 Selwyn PA, Hartel D, Lewis VA, et al. A prospective study of the risk of tuberculosis among intravenous drug users with human immunodeficiency virus infection. N Engl f Med 1989;320:545-50.

5 Braun MM, Badi N, Ryder R, et al. A retrospective cohort study of the risk of tuberculosis among women of childbearing age with HIV infection in Zaire. Am Rev Respir Dis 1990. (In press.)

6 Harries AD. Tuberculosis and human immunodeficiency virus infection in developing countries. Lancet 1990;335:387-90.

7 Clavel $\mathrm{F}$, Mansinho $\mathrm{K}$, Chamaret $\mathrm{S}$, et al. Human immunodeficiency virus type 2 infection associated with AIDS in west Africa. $N$ Engl $\mathcal{F}$ Med 1987;316:1180-5.

8 De Cock KM, Odehouri K, Colebunders RL, et al. A comparison of HIVand HIV-2 infections in hospitalised patients in Abidjan, Cote d'Ivoire. AIDS 1990;4:443-8.

9 Kanki PJ, M'Boup S, Ricard D, et al. Human T-lymphotropic virus type 4 and the human immunodeficiency virus in west Africa. Science 1987;236: 827-31

10 Romieu I, Marlink R, Kanki P, M'Boup S, Essex M. HIV-2 link to AIDS in west Africa. Journal of Acquired Immune Deficiency Syndromes 1990;3: 220-30.

11 Naucler A, Andreasson P-A, Mendes Costa C, Thorstensson R, Biberfeld G. HIV-2-associated AIDS and HIV-2 seroprevalence in Guinea-Bissau. foumal of Acquired Immune Deficiency Syndromes 1989;2:88-93.

12 SPSS. Statistical package for the social sciences. SPSSX advanced statistics guide. Chicago, Illinois: SPSS, 1985.

13 Hennekens CH, Buring JE. Attributable risk. In: Epidemiology in medicine. Boston: Little, Brown, 1987:87-95.

14 De Cock KM, Porter A, Odehouri K, et al. Rapid emergence of AIDS in Abidjan, Cote d'Ivoire. Lancet 1989;ii:408-11.

15 Odehouri K, De Cock KM, Krebs JW, et al. HIV-1 and HIV-2 infections associated with AIDS in Abidjan, Cote d'Ivoire. AIDS 1989;3:509-12.

16 Colebunders RL, Mann JM, Francis H, et al. Evaluation of a clinical case definition of acquired immunodeficiency syndrome in Africa. Lancet 1987;i:492-4.

17 Kanki PJ. West African human retroviruses related to STLV-III. AIDS $1987 \cdot 1 \cdot 141-5$

18 Poulsen A-G, Kvinesdal B, Aarby P, et al. Prevalence of and mortality from human immunodeficiency virus type 2 in Bissau, west Africa. Lancet $1989 ; \mathrm{i}: 827-31$

\title{
Prognosis and prognostic factors of retinal infarction: a prospective cohort study
}

\author{
Graeme J Hankey, James M Slattery, Charles P Warlow
}

\section{Abstract}

Objective-To determine the prognosis and adverse prognostic factors in patients with retinal infarction due to presumed atheromatous thromboembolism or cardiogenic embolism.

Design-Prospective cohort study.

Setting-University hospital departments of clinical neurology.

Patients-99 patients with retinal infarction, without prior stroke, referred to a single neurologist between 1976 and 1986 and evaluated and followed up prospectively until death or the end of 1986 (mean follow up $4 \cdot 2$ years)

Interventions-Cerebral angiography (55 patients), aspirin treatment (37), oral anticoagulant treatment (eight), carotid endarterectomy (13), cardiac surgery (six), and peripheral vascular surgery (two).

Main outcome measures -Death, stroke, coronary events, contralateral retinal infarction; survival analysis confined to 98 patients with retinal infarction due to presumed atheromatous thromboembolism or cardiogenic embolism (one patient with giant cell arteritis excluded), and Cox's proportional hazards regression analysis, including age as a prognostic factor.

Results-During follow up 29 patients died (21 of

Department of Clinical Neurosciences, Western General Hospital, Edinburgh EH4 2XU Graeme J Hankey, FRACP, research fellow

James M Slattery, MSC, statistician

Charles P Warlow, FRCP, professor of medical neurology

Correspondence to: Dr Hankey.

BMf 1991;302:499-504 prognostic factors for serious vascular events were increasing age and carotid bruit for stroke, and increasing age, cardiomegaly, and carotid bruit both for coronary events and for stroke, myocardial infarction, or vascular death.

Conclusions-Patients who present with retinal infarction due to presumed atherothromboembolism or cardiogenic embolism are at considerable risk of a coronary event. The risk of stroke, although high, is not so great. Not all strokes occurring after retinal infarction relate directly to disease of the ipsilateral carotid system, although this is probably the most common cause. Few patients experience contralateral retinal infarction. Non-arteritic retinal infarction should be diagnosed or confirmed by an ophthalmologist, and the long term care of patients with the condition should involve a physician who has an active interest in managing vascular disease.

\section{Introduction}

Retinal infarction may complicate a wide variety of diseases of the blood, heart, and arteries, and many patients with retinal infarction have a similar vascular disease and risk factor profiles to those with cerebral infarction. ${ }^{1-15}$ Because the effects of retinal infarction may be observed directly with an ophthalmoscope the condition may be regarded as an easily visible surrogate for cerebral infarction. Despite this, far less is known about the cause(s) and prognosis of retinal infarction. We have no sound data which allow us to advise patients about the risk of blindness in the other eye, stroke, or other serious vascular events such as myocardial infarction and sudden death of presumed cardiac cause. No prospective studies, and only a handful of retrospective studies, are available. ${ }^{341316-23}$

We report a prospective study of 98 patients who presented with retinal infarction without previous stroke, in whom complete follow up was achieved. Our aim was to determine the prognosis of retinal infarction for serious vascular events and to identify any prog- 